\title{
To strengthen the participate of the local community by marketing communication promoting sustainable tourism method The case study Khlong bang Luang Water market Bangkok.
}

\author{
Rinranee Seneewas
}

\begin{abstract}
This research aims to 1) study guidelines to to strengthen the participate of the local community by marketing communication promoting sustainable tourism method : The case study Khlong bang Luang water market Bangkok.

2) Study the guidelines promoting sustainable tourism 3 . Problems and obstacles in the participation of local communities markets, Khlong bang Luang Water market Bangkok The collection of data research conducted Interview Government

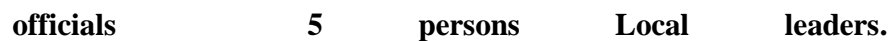
3) persons people in the community, 11 persons and data analysis, content analysis The interpretation of the data, create a conclusion

The research found that 1 study guidelines to To strengthen the participate of the local community by marketing communication promoting sustainable tourism method: The case study Khlong bang Luang Water market Bangkok will have to come from international cooperation government officials, leaders of the community stakeholders The benefits arising by developing and restoring the natural environment, lifestyle and environmental awareness in the community together and the promotion of tourism. (2) recommending promotion sustainable tourism must focus to conserve and maintain resources. keep it longest by the person concerned all cooperate as a network partner and the state support development focus continuous and research follow up

(3) Problems and obstacles in the floating market found still have comments mismatch in closing open the dam people local cooperating to conserve environment have moved come in society less effect lack of sincerity to solve environment land in society and the water is rotten in the canal unconscious to clean bang Luang narrow expandable including lack of support seriously and still participate of foreigners increase make a commitment of people.
\end{abstract}

Keywords - participate of the local community, marketing communication promoting

\section{INTRODUCTION}

A tourism is to promote sustainable tourism, so it is very important to the country and with the participation of the local community to develop a tourist attraction or activity is considered a form of action that is the task or related interests, the best life, cooperation activities regarding tourism. A community events also cause The widespread benefits. such as

Rinranee Seneewas, Siam Technology College, 46 Jarunsanitwong10 rd., Thapra branch, Bangkok-yai district, Bangkok 10600 Thailand. the ability to solve the trade deficit and the balance of payments of the country help increase revenue in the government's tax revenue is distributed to the local cause. An employment Creating jobs for people, causing widespread currency turnover.

The community area Phasi Charoen Bangkok is right to be promoted as a tourist attraction, such as a permanent farmland. It is old and historic temples Khuha Sawan Wadhnag Ratchaworawihan measured the wall of gold golden temple hall jobs Wat Indra create diamonds in a canal path from the river into the canal Khlong Bang Luang Canal and some houses have remained in original bulk as well as attractions such as Khlong Bang Luang artist house. The important factor is that foreign tourists to travel in the area, hundreds of people per day at present. This is where the local people have to cooperate more than in the past. In taking advantage of the area's development as a tourist aspire to a sustainable and attractive. The major attraction in Khuha Sawan Rd. And measured the wall of the gold market is Khlong Bang Luang. The market has a long history in the past because it is in a position where it was before the river. For the cultural sites for tourists to Bangkok and another in Thonburi.

The Floating Khlong Bang Luang community is located on the ancient route to transport Chao Phraya River, which was once a bustling trade and travel support from the public, private and administrative areas to encourage them to come back into the market again today as well as the rest of the holiday vacation. Local communities along Khlong Bang Luang area is reflected in the diversity of people in the community, according to the transitional period. A lifestyle and culture that remains under conditions to study and explore in a unique identity but the community Khlong Bang Luang trouble. public relations, public perception of the community (public information) consultation (public consultation) meetings to receive comments (public meeting) to participate in decision-making (decision making), so researchers are interested in studying strengthening the involvement of local communities with the means of communication, marketing case studies to promote sustainable tourism market Khlong Bang Luang, Bangkok.

\section{THIS RESEARCH AIMS TO}

1. study guidelines to To strengthen the participate of the local community by 
marketing communication promoting sustainable tourism method : The case study Khlong bang Luang Water market Bangkok.

2. study the guidelines promoting sustainable tourism

3. Problems and obstacles in the participation of local communities markets, Khlong

bang Luang Water market Bangkok.

\section{POPULATION}

The collection of data research conducted Interview Government officials 5 persons

Local leaders 3 persons people in the community, 11 persons and data analysis, content analysis The interpretation of the data, create a conclusion

\section{SCOPE OF RESEARCH}

In this research is qualitative research. The researchers determined the scope of the study are the following.

\section{A. Scope of content the contents of the study consisted of two} points is

1.1 foster the involvement of local communities in developing markets Khlong Bang Luang five areas:

1.1.1 to participate in the search problem

1.1.2 Participation in decision making.

1.1.3 participation in the operation

1.1.4 participation in the evaluation

1.1.5 participation in getting results.

\section{B. Guidelines for promoting sustainable tourism in two} forms:

2.1 The tour focused on resource conservation to maintain as long as possible.

2.2 The tourism-oriented education in natural resources. In order to maintain the ecosystem with regard to participation.

\section{Methodology}

The collection of data research conducted Interview Government officials 5 persons

Local leaders 3 persons people in the community, 11 persons and data analysis, content analysis The interpretation of the data, create a conclusion

\section{DATA COLLECTION}

1. Because the final formatting of your paper is limited in scale, you need A depth interview (interview), researchers have determined the point of questions prepared in advance. The main points of the interview will involve the development of local communities to be involved in the development, environment and tourism in local communities and guidelines for sustainable tourism management. Including joint problems and other suggestions.

2. discussion group (focus group) The main point of the discussion groups are offered. The relationship between the tourism market in Khlong Bang Luang local communities The issue of market Khlong Bang Luang Demand and the need to develop a Floating Khlong Bang Luang. For sustainable development in various aspects of the problems, the decision to conduct an evaluation of the results and comment on the management of sustainable tourism.

\section{DATA ANALYSIS}

1. A foster the involvement of local communities in developing markets Khlong Bang Luang

1.1 In search of a problem is found floating Khlong Bang Luang ecosystem is broken. Landscape Has been developed People in the community, lack of awareness on preserving the environment. The problem with the social/lifestyle. As a result, tourists Khlong Bang Luang travel market is not quite. The journey is not easy as it should be

1.2 To participate in the decisions that all citizens should be involved in ideas, problems and needs. And local leaders Or local politicians need to bring these problems and needs to continue. By emphasizing the awareness of environmental protection. Public relations and market Khlong Bang Luang,

1.3 Participation in the actions that public officials local religious leaders and stakeholders to co-operate in environmental conservation activities promotion of tourism. preparation of publicity materials

1.4 Participation in the evaluation found that all parties will be jointly evaluated by considering the reduction of conflicts. The restoration of the environment and lifestyle.

1.5 To participate in this process was the development activities of all parties to participate in the economic benefits in terms of revenue and pride. Interact better with each other and to get the popular vote of the people in the area.

2. Guidelines for sustainable tourism, found that the need to maintain a focus on resource conservation and keeping the longest of all the related parties to the collaboration, networking, and state support. highlight the continued development of tourism aimed at highlight the education in order to protect the ecological system is considered a conservation policy. Improve the landscape and solve environmental problems. Having consulted together. The training of the personnel involved using the principles of management and marketing communication process to highlight public relations and research evaluation.

3. Problems and obstacles

The development that provides feedback in regard to closing the sluice local residents cooperate to conserve the environment Has moved into the more exotic causes engagement of the community less. To solve problems A sewage canal The lack of awareness on cleanliness. The canal is cramped conditions can not be expanded. The lack of a serious and ongoing policy.

\section{DISCUSSION}

\section{A. The involvement of local communities in developing markets Khlong Bang Luang.}

In this study, the key findings in the development of society, the local community is that local residents have been involved 
review the market Khlong Bang Luang discusses the nature of the involvement of the community in the 5 reasons to participate in the invention. issue Participation in decision-making to participate in the action to participate in the evaluation and participate in the process by the following classification

1.1 To participate in the search for the public authorities local religious leaders and stakeholders together to find floating problems in Khlong Bang Luang. All groups agreed on environmental issues change issues social / lifestyle problems changing the behavior of people in the community. It can be seen that the public state officials local religious leaders and stakeholders are aware of the problems of the district. If these people get emotional support recognition support Information to receive news from various media support tools to promote given the opportunity to participate in activities and get various facilities.

1.2 participation in decision making. Public officers of the State. Religious leaders and other key stakeholders together, decided that all people must share and local leaders. Local politicians must take these problems and needs in the meetings to make action plans and issuing local legislation to improve the nature and landscapes unchanged citizen consciousness in environmental protection create a point of sale. improve the waterfront, water and waste disposal point, market development, canals, along with some capital market PR Khlong Luang, known as greater. If community leaders are aware of the roles and duties.

1.3 Participation in the implementation of public officials local religious leaders and stakeholders together campaign environmental rubbish into the canal does not encourage students to encourage microorganisms from waste water training local guides to provide knowledge to guide tourists preparation of publicity materials state officials local leaders and jointly push forward the action plan and develop action plans to improve and revitalize the market Khlong Bang Luang including the issuance of regulations

1.4 To participate in the evaluation public authorities local religious leaders and stakeholders agree that the budget allocated to development and reconstruction market Khlong Bang Luang and Wat Kamphaeng gold in the garbage development.

community museum Khlong Bang Luang with a view to adjusting the architectural design applications. The faculty of architecture Silpakorn University and marketing communications by recognizing the signs and QR Code for tourism awareness measured the wall in gold development community museum Khlong Bang Luang Khlong Bang Luang and waterfront community. affect public perception in a good way and contribute to greater development.

1.5 A participation in the evaluation of the state authorities, local leaders and religious persons, most have lost both the market. There were many people shop, travel. The neighborhood is a job occupation of various mesh support in the community, tourism can turnover. The currency the public revenue, economy is better. The pride in the way of life in a thai.
I favor generous share dependence are you a sibling interaction good friends when people travel dance It's in the area, the people.the owner of the need to improve the landscape. and well to point to tourists, local leaders and the government agencies and locations. A study on combined to private to have the help will get popularity from the people in the area, make an increase in cooperation between the local leaders, state officials, and those parts can be damaged as a result type The advantage of more by management Villagers to participate.

\section{B. Guidelines for promoting sustainable tourism.}

2.1 The tour focused on conservation. resources to maintain treatment for most public officials. local leaders local leaders stakeholders agree that the state must help to coordinate actively in the development of not allowing villagers to fight alone people in the community need to have cooperation with you as partners and awareness of resource conservation and environmental resources must be used in moderation reduced consumption more than necessary preserve and promote the natural diversity

2. 2 The tour that focuses on the study of natural resources in order to maintain the ecosystem with regard to participation all parties agree that agencies and concerned community leaders and district offices to focus a policy of antiquities landscape solutions, waste water and drainage improvements. The coordinator support the full participation of local authorities in the field of tourism. There are regular consultations between managed markets provide information featured in unison to promote the market Khlong Bang Luang and a collection of research data to monitor effectively to improve the ecology and living conditions to the satisfaction of tourists.

\section{Problems and obstacles}

In the development of a study that seems to be Problems to development. The group is a mismatch between the tour operator includes groups with merchants farmers in the group closed the sluice citizens to cooperate in conserving the environment moved into the more exotic causes engagement of the community, not less as before. hence, the lack of sincerity in solving the problems. There are chronic problems in wastewater. The lack of awareness on the cleanliness of the canal. Khlong Bang Luang cramped conditions can not be expanded and the lack of serious support and the continued relevance.

\section{RECOMMENDATIONS}

1. The findings should be found in the guidelines for the participation of local communities and promotion of participation and sustainability. applied in local development in those areas. The packed into a development plan for the local authority.

2. Should the findings of a needs urgent and important issue to be submitted to the competent authority to take action. 


\section{SugGestions FOR FURTHER RESEARCH}

This research is a qualitative research study on data from interviews with government officials and discussion groups The residents and the community and local leaders then analyzed using qualitative. The findings may not be comprehensive enough so the next time should be studied in depth, such as to store information in the long term participation in community activities others were involved and no involvement in community activities or the use of quantitative methods in enterprises, it makes it richer data. 